\title{
Analysis of Exhaust Emissions from Two Stroke Spark Ignition Engine with Copper Coated Piston Operating with Methyl Alcohol Blended Gasoline
}

\author{
Dr. K. Kishor \\ ${ }^{1}$ Assistant Professor, Mechanical Engineering Department, Chaitanya Bharathi Institute of Technology (CBIT), \\ Gandipet, Hydeabad, India
}

\begin{abstract}
Experiments were conducted to evaluate and control the exhaust emissions from two stroke single cylinder, spark ignition (SI) engine, with alcohol blended gasoline ( $80 \%$ gasoline, $20 \%$ methanol, by volume) having copper coated engine [CCE, copper(thickness, $300 \mu$ ) coated on piston crown] and compared with conventional SI engine (CE) with pure gasoline operation. The exhaust emissions of carbon monoxide (CO) and unburnt hydrocarbons (UBHC) were determined at different values of Brake Mean Effective Pressure (BMEP) with Netel Chromatograph CO/UBHC analyzer. Aldehyde levels were determined by Dinitrophenyl Hydrazine (DNPH) method. Copper coated combustion chamber with alcohol blended gasoline considerably reduced the pollutants in comparison with $C E$ with pure gasoline operation.
\end{abstract}

Keywords: Copper coating, carbon monoxide, unburnt hydrocarbons, formaldehydes, acetaldehydes.

\section{Introduction}

The paper is divided into i) Introduction, ii) Materials and Methods, iii) Results and Discussions, iv) Conclusions, Research Findings, Future scope of work followed by References.

For individual transport, SI engine is preferred to CI engine. Though two-stroke engine develops more power when compared with four-stroke engine, it faces criticism, as it emits higher pollution levels. Alcohols are the promising substitutes for the gasoline, being used in SI engines, as their properties are compatible to those of gasoline fuels. Because of their compatible properties to gasoline fuels, alcohols are considered to be the suitable substitutes for use in SI engines. When SI engines are run with alcohols, the major emissions are $\mathrm{CO}$ and $\mathrm{UBHC}$, besides aldehydes. $\mathrm{CO}$ is formed due to incomplete combustion [1]. When excess fuel is present and little oxygen is available, $\mathrm{CO}$ is formed. UBHC is formed due to ,quenching effect ${ }^{\text {ec }}$ [2]. The fuel will settle in the crevices of the piston and on the inner walls of the combustion chamber, which will come out during the exhaust stroke in the form of UBHC. When the engine is run with alcohols or alcohol blend, aldehydes [3] are formed as intermediate compounds in the combustion reactions. Aldehydes are carcinogenic in nature.

Kenny [4] carried out investigations to study the pollutant emissions from two-stroke SI engines and the methods to be adopted in decreasing the emissions. A number of approaches such as selective catalytic reduction technique to control the emissions were examined. Bata et al. [5] conducted experiments on a four-cylinder engine running at different conditions of equivalence ratio and spark timing. The effect on exhaust gas emissions ( $\mathrm{CO}, \mathrm{HC}$ and aldehydes) resulting from mixing methanol and/or ethanol with gasoline for automotive fuels has been studied experimentally. Results of this investigation indicated that the presence of either or both of the alcohols in fuel blends significantly reduced the concentration of $\mathrm{CO}$ in the exhaust emissions (up to 40-50 percent compared to pure gasoline only), with methanol slightly more effective than ethanol. Fulekar [6] explained that breathing of $\mathrm{CO}$ results in loss of appetite, an increased dizziness, and problems associated with respiration, burning of eyes and a decrease in the hemoglobin content of blood.

The present paper evaluated the exhaust emissions from two stroke copper coated engine with methanol blended gasoline (gasoline- $80 \%$, methanol- $20 \%$ by volume), which includes measuring the exhaust emissions of $\mathrm{CO}, \mathrm{UBHC}$ and Aldehydes at various values of brake mean effect pressure (BMEP) and compared with $\mathrm{CE}$ with pure gasoline operation. $\mathrm{CCE}$ with methyl alcohol blended gasoline reduced $\mathrm{CO}, \mathrm{UBHC}$ and aldehyde emissions over $\mathrm{CE}$ with pure gasoline operation

\section{Materials and Methods}

This section deals with fabrication of copper coated engine, description of experimental set up and measurement of exhaust emissions.

In the copper coated engine (CCE), a high thermal conductive catalytic material like copper was coated on the top surface of piston crown by flame spraying technique.

Plate 1 shows the photographic view of copper coated piston.

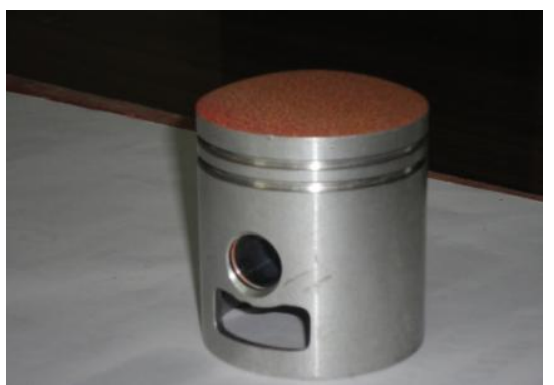

Plate 1 Photographic view of copper coated piston 


\section{International Journal of Science and Research (IJSR) \\ ISSN (Online): 2319-7064}

Index Copernicus Value (2013): 6.14 | Impact Factor (2014): 5.611

For $100 \mu$ thickness, nickel-cobalt-chromium bond coating was sprayed. On this coating, for another $300 \mu$ thickness, an alloy of copper $(89.5 \%)$, aluminium $(9.5 \%)$ and iron $(1 \%)$ was coated with a METCO (Trade name of the company) flame spray gun. The bond strength of the coating was so high that it does not wear off even after operating it for 50 hrs continuously [7]-[8].

Figure 1 shows the schematic diagram of the experimental set up that was employed to analyze the exhaust emissions.

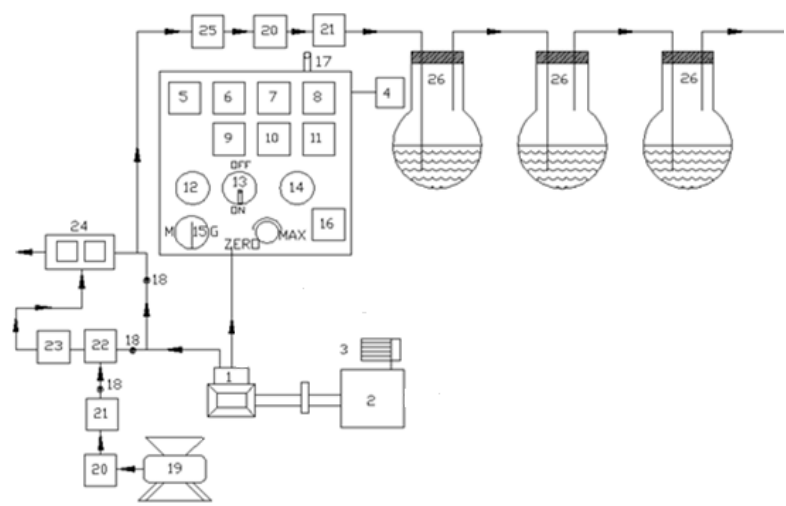

Figure 1: Schematic diagram of the experimental set up

1.Engine,2.Electrical swinging field dynamometer, 3.Loading arrangement, 4.Fuel tank, 5.Torque indicator/controller sensor, 6. Fuel rate indicator sensor, 7. Hot wire gas flow indicator, 8. Multi- channel temperature indicator, 9. Speed indicator, 10. Air flow indicator, 11. Exhaust gas temperature indicator, 12. Mains ON 13. Engine ON/OFF switch, 14. Mains OFF, 15. Motor/Generator option switch,16. Heater controller, 17. Speed indicator, 18. Directional valve, 19. Air compressor, 20. Rotometer, 21. Heater, 22. Air chamber, 23. Catalytic chamber, 24. CO/HC analyzer, 25. Filter, 26. Round bottom flasks containing DNPH solution

An air-cooled single-cylinder $2.2 \mathrm{~kW}$ BP two-stroke SI engine with a rated speed of $3000 \mathrm{rpm}$ was provided with an electrical swinging field dynamometer for the measurement of brake power (BP). A pressure-feed system provides the engine oil. $\mathrm{CO}$ and UBHC emissions in engine exhaust were measured with Netel Chromatograph analyzer. For measuring aldehydes in the engine exhaust a wet chemical method [9] was employed. The exhaust of the engine was bubbled through 2,4 DNPH in $\mathrm{HCl}$ [10]. solution and the hydrazones formed from aldehydes were extracted in to $\mathrm{CHCl}_{3}$ and were analyzed by HPLC [9]-[10] to find the \%concentration of formaldehydes and acetaldehydes in the engine exhaust.

\section{Results and Discussion}

This section deals with i). variation of $\mathrm{CO}$ emissions with BMEP, ii) variation of UBHC emissions with BMEP, and iii) data of Aldehyde emissions (Formaldehydes and Acetaldehydes)

\subsection{Exhaust Emissions}

Figure 2 shows the variation of $\mathrm{CO}$ emissions with brake mean effective pressure (BMEP) in CE with pure gasoline and CCE with methanol blended gasoline at a compression ratio of 7.5:1 and speed of $3000 \mathrm{rpm}$.

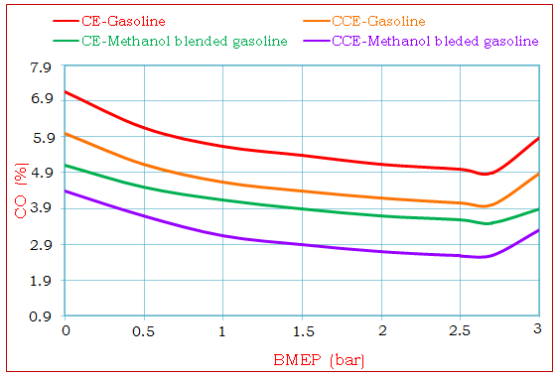

Figure 2: Variation of CO emissions with BMEP in CE and CCE with test fuels

From the Figure 2, it was noticed that, $\mathrm{CO}$ emissions decreased with increase of BMEP up to $80 \%$ of full load and later they increased in both configurations of the engine with both experimental fuels. In comparison with the base fuel, methyl alcohol blend decreased $\mathrm{CO}$ emissions in both configurations of the engine. With methyl alcohol operation fuel cracking reactions [7]-[8] would not take place, as the combustion of methyl alcohol was a result of hydroxil operation. In the molecular structure of methyl alcohol, the ratio of $\mathrm{C} / \mathrm{H}$ was lower $(0.25)$ compared to that of base fuel $(0.44)$. More oxygen was available with methyl alcohol in its composition which improved the combustion and hence the formation of $\mathrm{CO}$ emissions was decreased. The dissociation of methyl alcohol would result in the formation of hydrogen that results faster combustion. This faster combustion of fuel results the formation of $\mathrm{CO}_{2}$ and partial amount of $\mathrm{CO}$. Since the mixture was leaner $\mathrm{CO}$ was converted to $\mathrm{CO}_{2}$ and thus $\mathrm{CO}$ emissions were decreased. When compared to the base engine, $\mathrm{CO}$ emissions were decreased with the catalytic coated engine. Instead of formation of $\mathrm{CO}, \mathrm{CO}_{2}$ was formed with the catalytically activated engine, as catalytic coating promotes the combustion. Similar trends were noticed by other researchers [7]-[8] with base fuel operation on the catalytic coated engine.

The variation of UBHC emissions (ppm) with BMEP in CE and CCE with experimental fuels was shown in Figure 3.

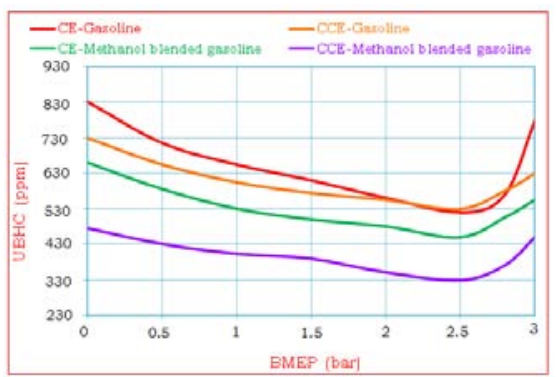

Figure 3: Variation of UBHC emissions with BMEP in CE and $\mathrm{CCE}$ with test fuels

Similar trends were observed from Figure-3 with UBHC emissions as in case of $\mathrm{CO}$ emissions in $\mathrm{CE}$ and CCE with both experimental fuels. This was because, with catalytic activity in CCE, flame speed increases and thus quenching effect decreases. This was also observed by other researchers [7]-[8] on CCE running with pure gasoline. 


\section{International Journal of Science and Research (IJSR) \\ ISSN (Online): 2319-7064}

Index Copernicus Value (2013): 6.14 | Impact Factor (2014): 5.611

Table 1 shows the data of Aldehyde emissions (Formaldehyde emissions and Acetaldehyde emissions, \% concentration) at full load operation of CE and CCE with experimental fuels.

Table 1: Data of aldehyde emissions ( $\%$ concentration) at full load operation of CE and CCE with test fuels

\begin{tabular}{|c|c|c|c|c|c|c|}
\hline Fuel used $\rightarrow$ & \multicolumn{3}{|c|}{ Pure gasoline } & \multicolumn{3}{|c|}{$\begin{array}{l}\text { Methanol blended } \\
\text { gasoline }\end{array}$} \\
\hline $\begin{array}{c}\text { Engine version } \\
\rightarrow\end{array}$ & \multirow{2}{*}{ CE } & \multirow{2}{*}{ CCE } & \multirow{2}{*}{$\begin{array}{c}\% \text { variation } \\
\text { with } \mathrm{CCE} \\
\text { over } \mathrm{CE}\end{array}$} & \multirow{2}{*}{$\mathrm{CE}$} & \multirow{2}{*}{$\mathrm{CCE}$} & \multirow{2}{*}{$\begin{array}{c}\% \text { variation } \\
\text { with CCE } \\
\text { over CE }\end{array}$} \\
\hline $\begin{array}{l}\text { Aldehyde } \\
\text { emissions } \downarrow\end{array}$ & & & & & & \\
\hline $\begin{array}{l}\text { Formaldehyde } \\
\text { emissions } \rightarrow\end{array}$ & 10.4 & 7.8 & $-25 \%$ & 27.1 & 15.6 & $-42.4 \%$ \\
\hline $\begin{array}{l}\text { Acetaldehyde } \\
\text { emissions } \rightarrow\end{array}$ & 8.8 & 5.6 & $-36.3 \%$ & 14.1 & 10.6 & $-24.8 \%$ \\
\hline
\end{tabular}

It was noticed from the Table 1 that, when the engine version is changed from base engine to $\mathrm{CCE}$, formaldehyde emissions and acetaldehyde emissions decreased by $25 \%$ and $36.3 \%$ respectively with pure gasoline operation, while they decreased by $42.4 \%$ and $24.8 \%$ respectively with methanol blended gasoline. This shows that catalytic coated engine was more suitable in reducing aldehyde emissions considerably because, there is no formation of highly reactive chemical compound due to increase of pre-flame reactions and turbulence. Other researchers [7]-[8] observed similar trends with the catalytic coated engine running with pure gasoline

\section{Conclusions}

1)CO emissions decreased by $44 \%$ with alcohol blended gasoline operation in CCE over pure gasoline operation in CE.

2)UBHC emissions decreased by $42.8 \%$ with alcohol blended gasoline operation in CCCC over pure gasoline operation in $\mathrm{CE}$.

3) With pure gasoline, CCE decreased formaldehyde emissions and acetaldehyde emissions by $25 \%$ and $36.3 \%$ respectively in comparison with $\mathrm{CE}$.

4) CCE decreased formaldehyde emissions and acetaldehyde emissions by $42.4 \%$ and $24.8 \%$ respectively with methanol blended gasoline when compared to $\mathrm{CE}$.

\section{Other recommendations}

Investigations on measurement of exhaust emissions with copper coating on top surface of piston were systematically investigated. Copper coating can also be done in addition on inner surface of cylinder head to decrease the pollutants further.

\section{Acknowledgements}

Author thanks the authorities of Chaitanya Bharathi Institute of Technology, Hyderabad for facilities provided. Financial assistance from Andhra Pradesh Council of Science and Technology (APCOST), Hyderabad, is greatly acknowledged. Authors sincerely thank authorities of M/S Sai Surface Coating (P) Limited, Patancheru, Hyderabad, for extending the cooperation in coating the components of the SI engine.

\section{References}

[1] Obert Edward Frederic, Internal Combustion Engines and Air Pollution, In text educational publishers, New York, 1973.

[2] Marco Nuti, "Emissions from Two-Stroke Engines", Warrandale PA: SAE, 1998.

[3] M. Ronald Heck, J. Robert Farauto, Catalytic Air Pollution Control, John Wiley \& sons, 2009.

[4] R.G. Kenny, "Developments in Two Stroke Cycle Engine Exhaust Emissions," In Proceedings of the Institution of Mechanical Engineers, Part D: Journal of Automobile Engineering, Vol. 206, No. D2, 1992.

[5] R.V. Bata, V.P. Roan, "Effects of Ethanol and/or Methanol in Alcohol-Gasoline Blends on Exhaust Emission," Journal of Engineering for Gas Turbines and Power, Vol. 111, No. 3, pp. 432-438, 1989.

[6] M.H. Fulekar, "Chemical Pollution - A Threat to Human Life", Indian Journal of Environmental Protection, Vol. 1, No. 3, pp. 353-359, 1999.

[7] S. Dhandapani, "Theoretical and Experimental Investigation of Catalytically Activated Lean Burn Combustion," Ph. D. Thesis, Indian Institute of Technology, Madras, 1991.

[8] N. Nedunchezhian, S. Dhandapani, "Experimental Investigation of Cyclic Variation of Combustion Parameters in a Catalytically Activated Two Stroke SI Engine Combustion Chamber," Engineering Today, ISSN: 0974-8377, Vol. 2, pp. 11-18, 2000.

[9] Inove To Kuta, Oishi Kiyohiko, Tanaka To Shiaki, "Determination of Aldehydes in the Automobile Exhaust By HPLC," Toyota Automobile Company, Technical Improvement Division, Toyota, Japan, Vol. 21, No. 4, pp. 500-506, 1980.

[10] P.V.K. Murthy, S. Narasimha Kumar, M.V.S. Murali Krishna, V.V.R. Seshagiri Rao, D.N. Reddy, "Aldehyde Emissions from Two-Stroke and Four-Stroke Spark Ignition Engines with Methanol Blended Gasoline with Catalytic Converter," International Journal of Engineering Research and Technology, ISSN: 09743154, Vol. 3, No. 3, pp. 739-802, 2010.

\section{Author Profile}

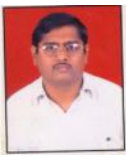

Dr. K. Kishor received the B.Tech.. degree in Mechanical Engineering, M.Tech. degree in Thermal Engineering and Ph.D. from Jawaharlal Nehru Technological University, Hyderabad in 1987, 2005 and 2014 respectively. Till now, he worked in various capacities in the teaching profession for a total period of 27 years. Since 2004, he is working as Senior Assistant Professor in Mechanical Engineering Department, Chaitanya Bharathi Institute of Technology (CBIT), HYDERABAD. 